\title{
EVALUATION OF ANTHELMINTIC ACTIVITY OF CITRUS RETICULATA: IN VITRO AND ITS PHYTOCHEMICAL INVESTIGATION
}

\author{
ARJAN ARYAL ${ }^{1 *}$, SABITA UPRETI², KUNTAL DAS ${ }^{3}$
}

${ }^{1}$ Department of Pharmacy Practice, Krupanidhi College of Pharmacy, Bengaluru, Karnataka, India. ${ }^{2}$ Department of Pharmacology, Krupanidhi College of Pharmacy, Bengaluru, Karnataka, India. ${ }^{3}$ Department of Pharmacognosy, Krupanidhi College of Pharmacy, Bengaluru, Karnataka, India. Email: mynameisarjan@gmail.com

Received: 31 January 2016, Revised and Accepted: 24 February 2017

\section{ABSTRACT}

Objective: The prevalence of worm infestation is high in underdeveloped and developing countries due to poor sanitation and lack of health education. Citrus reticulata, fruit belonging to citrus family Rutaceae is a common fruit native to Asia. Peels of the fruit are rich in limonene, a potent phytoconstituent having anthelmintic activity. However, proper utilization of peels has not been done as it is not consumed and is therefore discarded. The main objective of the study was to explore various phytoconstituents present in C. reticulata and its anthelmintic effect.

Methods: Various concentration of methanolic extract and volatile oil of $C$. reticulata were subjected for assessment of anthelmintic activity in earthworms. Time of paralysis and time of death were used as an evaluation parameter. Albendazole ( $25 \mathrm{mg} / \mathrm{ml}) \mathrm{was}$ used as a standard drug.

Results: Phytochemical test revealed the presence of alkaloids, carbohydrates, tannins, flavonoids, terpenoids, and glycosides. Concentrationdependent anthelmintic effect was observed with the extract were $150 \mathrm{mg} / \mathrm{ml}$ concentration of methanolic extract showed paralysis of test worm (earthworm) at 5.76 minutes and death at 19.16 minutes, respectively.

Conclusion: $C$. reticulata peel has shown substantial anthelmintic activity using in vitro model on earthworms. Hence, further research is required to understand its mechanism of action using in vivo models to confirm its anthelmintic potential.

Keyword: Citrus reticulata, Anthelmintic activity, Phytochemical constituents, Pheretima phostuma.

(C) 2017 The Authors. Published by Innovare Academic Sciences Pvt Ltd. This is an open access article under the CC BY license (http://creativecommons. org/licenses/by/4. 0/) DOI: http://dx.doi.org/10.22159/ajpcr.2017.v10i5.17406

\section{INTRODUCTION}

Helminthiasis is one of the most widespread infectious disease affecting mostly children and pregnant women. Around 2 billion people are infected by helminths (Ascaris lumbricoides, hookworm, Trichuris trichiura, and Hymenolepsis nana) especially in the developing countries having poor sanitation [1]. Citrus reticulata commonly referred to as Mandarin orange or Tangerine is a sweet, juicy, easy to peel citrus fruit belonging to family Rutaceae. In Sanskrit, it is called Narangi and is originated in South East Asia. It is the second most widely cultivated citrus fruit after sweet orange (Camellia sinensis) and is cultivated well in countries such as Vietnam, Japan, Southern China, and Nepal.

They are orange colored small fruit bearing easily divided sections with loose skin. Fruit is rich in vitamin C, Vitamin A, flavonoids such as narirutin and hesperidin [2], phenolic acids, volatile oil, minerals such as calcium and potassium [2]. Dry fruit rind of the plant is edible, used as flavoring agent having sweet, spicy flavor. Fruits are consumed as juice or eaten fresh, used in beverages and preparation of jams and candies. Apart from its high nutritional value, it also has high medicinal value. Fruits are laxative, anthelmintic and aphrodisiac [3] as it possesses chemical constituents such as limonoid glycoside [4], flavonoid glycoside like - Kaempfer ride trimethyl ether; quercetin 3, 7, 3', 4'tetramethyl ether, steroids, $\lambda$ terpinene, and few flavones [5]. Oil obtained from fruit pulp has been traditionally used as sedative, diuretic, antispasmodic, antiseptic and in improving blood circulation [6]. In Ayurveda, dried peel has been used in the regulation of abdominal distension to enhance digestion and decrease phlegm. D-Limonene is a major constituent along with $\alpha$ - pinene and $\beta$ - pinene in the oil extract of the fruit peel and is responsible for its antimicrobial property [7]. It has skin sensitizing effect in the presence of sunlight which is due to the presence of a coumarin; bergapten [8]. It also has anti-proliferative effect on various cancer cell lines such as human gastric cancer cells (SNU-668) and colon cancer cells (SNU-C4) [9], used to treat dyspepsia, hiccups, and vomiting. It possesses various pharmacological activities such as antibacterial [10], antifungal, anti-inflammatory, and anticancer activities.

Therefore, due to its high nutritional and medicinal value, the anthelmintic potential of this particular species of Citrus family has been chosen to explore its preliminary phytochemical constituents and in vitro anthelmintic effect.

\section{METHODS}

\section{Plant}

Fruit of $C$. reticulata (mandarin) was purchased from local market of Bengaluru, South India. The plant and the plant material were identified and authenticated by Dr. Shivananda T.N, Principal Scientist, Department of Medicinal and Aromatic Plant, Indian Institute of Horticultural Research, Bengaluru, India and thereafter voucher herbarium specimen No: CR-311/KCP was preserved in the Department of Pharmacognosy in Krupanidhi College of Pharmacy, Bengaluru, India.

\section{Preparation of extract}

Fruits were washed thoroughly using tap water and were peeled off manually. All the peels were segregated into two halves where onehalf were shade dried at room temperature for 10-12 days. The dried peels were further made to smaller size and its methanolic extract was prepared by soxhlation technique.

\section{Volatile oil extraction}

Volatile oil was obtained from the remaining half of fresh peels $(750 \mathrm{~g})$ by Clevenger's apparatus in 3 batches using distilled water as solvent 
and temperature was maintained at $45^{\circ} \mathrm{C}$. Slight yellow colored volatile oil was obtained with a yield of $0.11 \%$.

\section{Experimental animal}

The ethical clearance was obtained from the Institutional Animal Ethics Committee (Approval No: 2015/PCOL/05). The experiment was conducted using Indian Adult earthworm (Pheretima posthuma) which was purchased from University of Agricultural Sciences, GKVK, Bengaluru - 65. The earthworms of 6-8 $\mathrm{cm}$ in lengths and $0.2-0.4 \mathrm{~cm}$ in width were used for all the experimental protocol. Before initiating the experiment, earthworms were in normal saline to remove the waste/unwanted matter. Since earthworms aid in increasing the fertility of the soil and are easily available in fields; also they anatomically and physiologically resemble the human intestinal roundworm parasite A. lumbricoides. Therefore, earthworms have been selected as an experimental animal for the preliminary evaluation of anthelmintic activity, in vitro.

\section{Drugs and chemicals}

Methanolic extract and volatile oil of the peel of $C$. reticulata fruit, albendazole (Intas Pharmaceuticals LTD, Ahmedabad), dimethyl sulfoxide, $0.9 \% \mathrm{NaCl}$, anhydrous formic acid of analytical grade were used during the experimental protocol.

\section{Phytochemical screening}

The methanolic extract of the dried peels was screened for the presence of various phytoconstituents such as alkaloids, glycosides, carbohydrates, tannins, flavonoids, and steroids qualitatively as per the standard protocol [11].

\section{Anthelmintic assay}

Anthelmintic activity was assessed in such a way that two earthworms were placed on each Petri dish consisting of $20 \mathrm{ml}$ of solution. Methanolic extract of orange peel at four different concentrations $(25,50,100$ and $150 \mathrm{mg} / \mathrm{ml})$, orange peel oil at $(0.5 \%, 1 \%, 1.5 \%$ and $2 \%)$ concentrations was used as test while albendazole at the concentration of $25 \mathrm{mg} / \mathrm{ml}$ was used as reference standard and control was normal saline. Observation for the time of paralysis and death of worms were used as an evaluation parameter in which worm was considered to be paralyzed if it shows no movement except when shaken vigorously. Time of death was recorded if the worm does not show movement even after shaking externally or when placed on $50^{\circ} \mathrm{C}$ water or if the colour of worm fades away [12]. All the results shown in Table 1 are expressed as a mean \pm standard error of mean of six worms in each group [13].

\section{RESULT}

\section{Preliminary phytochemical screening}

The preliminary phytochemical screening revealed the presence of various phytoconstituents in the extract. It showed the presence of carbohydrates, flavonoids, alkaloids, terpenoids, phytosterols, tannins, and steroids and the results are compiled in Table 2 .

\section{Anthelmintic assay}

The in vitro anthelmintic activity of peels of Citrus reticulata was evaluated in earthworms using parameters; Time of paralysis and Time of death which is shown in Table 2 .

\section{DISCUSSION}

Preliminary phytochemical investigation showed the presence of alkaloids, glycosides flavonoids, carbohydrates, tannins, steroids, and terpenoids in the methanolic extract which might be responsible for its potent anthelmintic activity. Limonene has been reported to be a major active principle in citrus peels and it has shown anthelmintic activity in ruminants [14]. Orange being a citrus fruit, volatile oil from its peel also consists of high amount of limonene. Anthelmintic assay when performed in vitro on earthworm, both the extract as well as volatile oil exhibited anthelmintic effect in a dose-dependent manner (Table 1). From the above result, all the concentrations of the extract of $C$. reticulata and its volatile oil were found to exhibit strong
Table 1: Anthelmintic activity of $C$. reticulata

\begin{tabular}{|c|c|c|c|}
\hline \multirow[t]{2}{*}{ Extract } & \multirow{2}{*}{$\begin{array}{l}\text { Concentration } \\
(\mathrm{mg} / \mathrm{ml})\end{array}$} & \multicolumn{2}{|l|}{ Mean士SEM } \\
\hline & & $\begin{array}{l}\text { Time of } \\
\text { paralysis } \\
\text { in minutes }\end{array}$ & $\begin{array}{l}\text { Time of } \\
\text { death in } \\
\text { minutes }\end{array}$ \\
\hline Normal saline & - & - & - \\
\hline \multirow[t]{4}{*}{ Methanolic extract } & 25 & $38.28 \pm 0.32$ & $57.71 \pm 0.58$ \\
\hline & 50 & $26.52 \pm 0.31$ & $37.89 \pm 0.51$ \\
\hline & 100 & $8.42 \pm 0.19$ & $28.18 \pm 0.64$ \\
\hline & 150 & $5.76 \pm 0.19$ & $19.16 \pm 0.60$ \\
\hline $\begin{array}{l}\text { Albendazole } \\
\text { (standard) }\end{array}$ & 25 & $1.44 \pm 0.04$ & $4.63 \pm 0.36$ \\
\hline \multirow{4}{*}{$\begin{array}{l}\text { Volatile orange } \\
\text { peel oil }\end{array}$} & 0.5 & $18.21 \pm 0.11$ & $80.48 \pm 0.26$ \\
\hline & 1 & $16.66 \pm 0.25$ & $56.43 \pm 0.44$ \\
\hline & 1.5 & $12.60 \pm 0.28$ & $46.88 \pm 0.98$ \\
\hline & 2 & $10.66 \pm 0.37$ & $32.22 \pm 0.61$ \\
\hline
\end{tabular}

C. reticulata: Citrus reticulata SEM: Standard error mean, each value represents mean \pm SEM $(n=6)$

Table 2: Preliminary phytochemical tests on methanolic extract of $C$. reticulata

\begin{tabular}{ll}
\hline Test & Methanolic extract of \\
& C. reticulata \\
\hline Test for carbohydrates & \\
Fehling's test & ++ \\
Benedict's test & ++ \\
Test for alkaloids & + \\
Mayer's test & + \\
Wagner's test & \\
Test for glycosides & ++ \\
Legal's test & + \\
Baljet test & \\
Test for steroids & ++ \\
Salkowski test & + \\
Libermann-Burchard test & \\
Test for saponins & - \\
Foam test & \\
Test for flavonoids & ++ \\
Shinoda test & + \\
Lead acetate test & \\
Test for protein & - \\
Biuret test & + \\
Test for tannins and phenolic compounds & + \\
FeCl test & + \\
Gelatin solution test & + \\
Test for phytosterols & + \\
Test for terpenoids & + \\
\hline
\end{tabular}

More prominent color observed (++), Less prominent color observed (+) absent (-), C. reticulata: Citrus reticulata

anthelmintic effect when compared to standard drug. At concentration of $150 \mathrm{mg} / \mathrm{ml}$, methanolic extract of $C$. reticulata showed paralysis at $5.76 \pm 0.19$ minutes and death at $19.16 \pm 0.60$ minutes while $2 \%$ concentration of volatile oil showed paralysis at $10.66 \pm 0.37$ minutes and death at $32.22 \pm 0.61$ minutes. These two concentrations showed better anthelmintic effect when compared to others. Albendazole showed paralysis of earthworm at $1.44 \pm 0.04$ minutes and death after $4.63 \pm 0.36$ minutes. Limonene is a major constituent of citrus fruits but its exact mechanism of anthelmintic effect is not identified, but several former research on limonene suggests its inhibitory effect on the plasma membrane pumps, growth of nematodes, enzymes of parasite and it certainly disturbs the metabolic pathway of the worms.

\section{CONCLUSION}

From the results obtained through our studies, it can be concluded that $C$. reticulata has a potent anthelmintic effect. The peel of the fruit 
is generally not utilized but has high value. Therefore with the help of this knowledge, further research has to be conducted to find out the exact mechanism and isolate the active principle responsible for its anthelmintic effect which can aid in exploring a novel anthelmintic drug.

\section{ACKNOWLEDGMENT}

The authors are grateful to the principal and management of Krupanidhi College of Pharmacy for providing necessary facilities required for carrying out the research work.

\section{REFERENCES}

1. Helminthiasis. World Health Organization; 2016. Available from: http://www.who.int/tdr/diseases-topics/helminths/en. [Last cited on 2016 Oct 24].

2. Vesna T, Gordana S, Sonja M, Jasna M, Jelena J, Knez Z, et al. Antioxidant activity of mandarin (Citrus reticulata) Peel. APTEFF 2010;41:1-203.

3. Kirtikar KR, Basu BD. Indian Medicinal Plants. Vol. 1. India: Lalit Mohan Basu and Co.; 1935. p. 451

4. Saxena VK, Shrivastava P. 3-methoxy flavones: The potential antiviral agents from Citrus reticulata, Blanco. Asian J Chem 1995;7(1):157-60.

5. Adeleke AK, Oladipupo AL, Olatunji TA, Abayomi AO, William NS. Citrus essential oils of Nigeria part IV: Volatile constituents of leaf oils of mandarins (Citrus reticulata Blanco) from Nigeria. Rec Nat Prod 2010;4(3):156-62.
6. Burkill HM. The Useful Plants of West Tropical Africa, Families M-R. $2^{\text {nd }}$ ed., Vol. 1. United Kingdom: Royal Botanical Garden Kew; 1984. p. 647.

7. Ayoola GA, Johnson OO, Adelowotan T, Aibinu IE, Adenipekun E, Adepoju-Bello AA, et al. Evaluation of the chemical constituents and the antimicrobial activity of the volatile oil of Citrus reticulata fruit (Tangerine fruit peel) from South West Nigeria. Afr J Biotechnol 2008;7(13):2227-31.

8. Dugrand-Judek A, Olry A, Hehn A, Costantino G, Ollitrault P, Froelicher Y, et al. The distribution of coumarins and furanocoumarins in citrus species closely matches citrus phylogeny and reflects the organization of biosynthetic pathways. PLoS One 2015;10(11):e0142757

9. Kang SA, Park HJ, Kim MJ, Lee SY, Han SW, Leem KH. Citri reticulata viride pericarpium extract induced apoptosis in SNU-C4, human colon cancer cells. J Ethnopharmacol 2005;97(2):231-5.

10. Li Y, Xu C, Zhang Q, Liu JY, Tan RX. In vitro anti-Helicobacter pylori action of 30 Chinese herbal medicines used to treat ulcer diseases. J Ethnopharmacol 2005;98(3):329-33.

11. Kokate CK. Pharmacognosy. $16^{\text {th }}$ ed. Mumbai, India: Nirali Prakhasan; 2001.

12. Deb PK, Ghosh R, Das S, Bhakt T. In vitro anthelminthic activity of Acorus calamus. Asian J Pharm Clin Res 2013;6(3):135-7.

13. Kosalge SB, Fursule RA. Investigation of in vitro anthelmintic activity of Thespesia lampas (Cav.). Asian J Pharm Clin Res 2009;2(2):69-71.

14. Squires JM, Foster JG, Lindsay DS, Caudell DL, Zajac AM. Efficacy of an orange oil emulsion as an anthelmintic against Haemonchus contortus in gerbils (Meriones unguiculatus) and in sheep. Vet Parasitol 2010;172(1-2):95-9. 